\title{
BIOSTRATIGRAPHY OF THE UPPER PART OF MAL PASO FORMATION (ALBIAN) IN THE AREA OF SAN LUCAS, MICHOACAN.
}

CHÁVEZ, Luis G., Museo de Paleontología, Facultad de Ciencias, UNAM, México, D.F., 04510; GARCÍA, Pedro B., Museo de Paleontología, Facultad de Ciencias, UNAM, México, D.F., 04510.

The aim of this work was to study the stratigraphic distribution of invertebrate fossil species found in an outcrop near San Lucas town, Michoacan state, Mexico. The fossiliferous strata belong to the upper member of Mal Paso Formation, originally proposed in 1959 by Pantoja-Alor.

A whole of twenty one fossil species were found: one of foraminifers, one of corals, four of pelecypods and fifteen of gastropods.

Faunistic analysis and rock types show that these communities lived in a shallow marine tropical environment, with lagoon or post-reef facies.

The stratigraphic ranges of species allowed to establish an Early Albian age for the bearing rocks, and clear relationships with several outcrops in Mexico and other parts of the world, inside of what is known as the Tethys realm. 